\title{
Aromatase inhibitors in men: effects and therapeutic options
}

Willem de Ronde ${ }^{1}$ and Frank $\mathrm{H}$ de Jong ${ }^{2^{*}}$

\begin{abstract}
Aromatase inhibitors effectively delay epiphysial maturation in boys and improve testosterone levels in adult men Therefore, aromatase inhibitors may be used to increase adult height in boys with gonadotropin-independent precocious puberty, idiopathic short stature and constitutional delay of puberty. Long-term efficacy and safety of the use of aromatase inhibitors has not yet been established in males, however, and their routine use is therefore not yet recommended.
\end{abstract}

\section{Background}

Over the past 15 years it has become evident that in men estradiol is responsible for a number of effects originally attributed to testosterone. Estradiol has an important role in gaining and maintaining bone mass, closing of the epiphyses and the feedback on gonadotropin secretion. This fact became particularly evident in men with aromatase deficiency. Aromatase is the enzyme responsible for conversion of androgens to estrogens. Men with estrogen deficiency caused by a mutation in the CYP19 gene suffer from low bone mineral density (BMD) and unfused epiphyses, and have high gonadotropin and testosterone levels [1]. Estrogen excess in turn has been associated with premature closure of the epiphyses, gynecomastia and low gonadotropin and testosterone levels. Lowering estrogen levels in men has emerged, consequently, as a potential treatment for a number of disorders including pubertas praecox, the andropause (also referred to as late-onset hypogonadism) and gynecomastia. Aromatase inhibitors were proven to be safe, convenient and effective for the treatment of hormone sensitive breast cancer in women although their use is associated with a modest increase in bone resorption $[2,3]$. This review will discuss the potential targets and the evidence for the use of aromatase inhibitors in men and adds more recent data to the text of an earlier review on this subject [4].

\footnotetext{
* Correspondence: f.h.dejong@erasmusmc.nl

${ }^{2}$ Department of Internal Medicine, Erasmus university Medical Center, P.O. Box 2040, 3000 CA, Rotterdam, The Netherlands Full list of author information is available at the end of the article
}

\section{Metabolism of estrogens in men}

Aromatase, also known as estrogen synthetase, is the key enzyme in estrogen biosynthesis. The enzyme, localized in the endoplasmic reticulum of the estrogen-producing cell, is encoded by the CYP19A1 gene. This gene is a member of the $C Y P$ gene family, encoding a class of enzymes active in the hydroxylation of endogenous and exogenous substances. The CYP19A1 gene is localized on chromosome 15 and comprises nine exons; the start codon for translation is located on exon 2. Transcription of the aromatase gene is regulated by several tissue-specific promoters. These promoters are under the influence of different hormones and growth factors such as gonadotropins (gonadal promoter II) and interleukin-6, interleukin-11 and tumor necrosis factor-a (adipose/ bone promoter I.4; for review see [5]). Aromatase activity has not only been demonstrated in gonads and placenta but also in brain [6], fat tissue [7,8], muscle [9], hair [10], bone [11] and vascular tissue [12].

Estradiol is the most potent estrogen produced in the body. It is synthesized from testosterone or estrone via aromatase or $17 \beta$-hydroxysteroid dehydrogenase, respectively. The total estradiol production rate in the human male has been estimated to be 35-45 $\mu \mathrm{g}$ (0.130-0.165 $\mu \mathrm{mol})$ per day, of which approximately $20 \%$ is directly produced by the testes $[13,14]$. Roughly $60 \%$ of circulating estradiol is derived from direct testicular secretion or from conversion of testicular androgens. The remaining fraction is derived from peripheral conversion of adrenal androgens [15]. The mean estradiol plasma concentration in men is only about $1 / 200$ of the mean plasma testosterone concentration [16] and is
C Biomed Central 
comparable to estradiol levels found in women in the early follicular phase of the menstrual cycle.

\section{Phenotype of aromatase deficiency and excess}

To date, eight males with aromatase deficiency have been described: seven adults [17-23] and one newborn [24]. Estradiol levels in these males were extremely low. All adult aromatase-deficient men demonstrated a remarkably low bone mass and unfused epiphyses leading to linear growth into adulthood and above-average body length. Testicular size in these men ranged from micro- to macroorchidism and the plasma testosterone levels varied roughly in accordance with testis size. Levels of luteinizing hormone $(\mathrm{LH})$ were either normal or elevated. Four men were infertile, in one younger male fertility was not described. Two aromatase-deficient men had a brother who also suffered from infertility despite a normal aromatase genotype, suggesting an unrelated second condition. Once treated with estradiol, epiphyses closed, BMD increased and disturbances in the lipid profile improved in most of these patients.

On the other hand, several, mostly familial cases of aromatase excess have been reported. The clinical picture consists of gynecomastia, accelerated growth and premature bone maturation due to excessive peripheral estrogen synthesis. Stratakis et al. [25] described a family with aromatase excess syndrome in which the syndrome appeared to be caused by inappropriately high expression of an alternative first exon. Shozu et al. [26] described a father and his son and one unrelated patient with aromatase excess caused by a chromosomal rearrangement, which placed the aromatase gene adjacent to cryptic promoters. As a result an inappropriate amount of aromatase was expressed in adipose tissue of the affected subjects.

These case reports illustrate the important contribution of estrogens to male health and identify the possible indications and risks of aromatase-inhibitor treatment in men. Aromatase inhibitors may be used to treat or prevent gynecomastia. They may be used to increase gonadotropin secretion and thereby stimulate Leydig and Sertoli cell function. Aromatase inhibitors may be used to prevent or delay epiphysial closure and thereby increase adult height. A major concern of aromatase inhibition is the possible detrimental effect on bone mineralization.

\section{Aromatase inhibitors}

Aromatase inhibitors are classified as either steroidal or nonsteroidal, or as first, second or third generation. Steroidal inhibitors such as formestane and exemestane inhibit aromatase activity by mimicking the substrate androstenedione. Nonsteroidal enzyme inhibitors such as anastrozole and letrozole inhibit enzyme activity by binding with the heme iron of the enzyme. First-generation aromatase inhibitors such as aminoglutethimide are relatively weak and nonspecific; they can also block other steroidogenic enzymes necessitating adrenal steroid supplementation. Third-generation inhibitors such as letrozole and anastrozole are potent and do not inhibit related enzymes. They are well tolerated and apart from their effects on estrogen metabolism their use does not appear to be associated with important side effects in postmenopausal women [27]. Although aromatase inhibition by anastrozole and letrozole is reported to be close to $100 \%$, administration of these inhibitors to men will not suppress plasma estradiol levels completely. In men thirdgeneration aromatase inhibitors will decrease the mean plasma estradiol/testosterone ratio by $77 \%[28,29]$. This finding probably relates to the high plasma concentrations of testosterone, a major precursor for estradiol synthesis in adult men. As aromatase inhibition is dose dependent it has been suggested that aromatase is less suppressed in the testis compared to adipose and muscle tissue, explaining the incomplete efficacy of aromatase inhibition in men. Aromatase activity is high in the testes and the molar ratio of testosterone to letrozole is much higher in the testes compared with adipose and muscle tissue. When testicular testosterone and estradiol synthesis are suppressed and testosterone is administered exogenously in combination with letrozole, however, the estradiol/testosterone ratio is suppressed by $81 \%$ [30], which is only marginally different from the suppression of this ratio in intact men after treatment with letrozole. This incomplete suppression may be regarded as advantageous for it prevents excessive reduction of estrogen levels in men and the possible associated adverse effects. In postmenopausal women with breast carcinoma, longterm use of potent aromatase inhibitors reduces circulating estradiol levels by $88 \%$ [31] and is associated with adverse effects on bone $[2,3]$. Due to the much higher estrogen levels in treated men it remains to be determined whether this also holds true for men.

\section{Effects of aromatase inhibition on luteinizing hormone release and testosterone production}

It is well known from experimental evidence and from clinical observations that estradiol has powerful effects on gonadotropin release in men. Modulation of plasma estradiol levels within the male physiological range is associated with strong effects on plasma levels of $\mathrm{LH}$ through an effect at the level of the pituitary gland [32]. Lowering estradiol levels, by administering an aromatase inhibitor, is associated with an increase in levels of LH, follicle-stimulating hormone (FSH) and testosterone $[28,29]$. Aromatase inhibitors, therefore, have been suggested as a tool to increase testosterone levels in men with low testosterone levels. Due to their mode of action the use of aromatase inhibitors is limited to men with at 
least some residual function of the hypothalamo-pituitary-gonadal axis. Therefore aromatase inhibitors have been tested in older men suffering from so-called lateonset hypogonadism or partial androgen deficiency. Aging in men is associated with a gradual decline of total and free testosterone levels [33] as a result of combined testicular and hypothalamic dysfunction. The decline of testosterone levels has been implicated in the pathogenesis of physical frailty in older men. Androgen treatment, therefore, has been advocated for older men with signs and symptoms of androgen deficiency and unequivocally low plasma testosterone levels $[34,35]$.

Aromatase inhibitors may be an attractive alternative for traditional testosterone substitution in elderly men because these compounds can be administered orally once daily and may result in physiological $24 \mathrm{~h}$ testosterone profiles. Additionally, misuse of aromatase inhibitors is unlikely since testosterone levels will not be stimulated to vastly supraphysiological levels. A small, controlled study demonstrated that anastrozole in a dose of $1 \mathrm{mg}$ daily during 12 weeks will result in doubling of the mean bioavailable testosterone level in older men [36]. A more recent study also showed a moderate but significant effect of aromatase inhibition on estradiol and testosterone levels in older men [37]. Treatment with atamestane $100 \mathrm{mg}$ once daily resulted in a $40 \%$ increase in total testosterone levels after 36 weeks. However, no beneficial effects were seen on muscle strength, body composition or quality-of-life scores. A similar increase of testosterone levels in the absence of effects on body composition and strength was reported in a study, in which elderly men with borderline low levels of serum testosterone were treated with anastrozole during 1 year [38]. There is a number of possible explanations for the lack of a clear treatment effect. First of all, the numbers of studied subjects were relatively small. Moreover, the mean baseline testosterone levels in the treated groups were in, or only slightly below, the normal range for young adult men and the relative increase in testosterone levels may have been too small. It has been suggested that men with the lowest baseline testosterone levels benefit most from testosterone substitution [39]. Finally, the decreased levels of estradiol may have affected the expected rise in lean body mass [38]. These observations outline a serious limitation of the use of aromatase inhibitors in older men; the stimulating effect on testosterone levels may be too weak, especially in the men with the lowest baseline testosterone levels who would potentially benefit most.

\section{Effects of aromatase inhibition in obese men}

Peripheral androgen aromatization is enhanced in subjects with increased body mass index [40]. Massively obese men show markedly increased plasma estradiol concentrations and low testosterone concentrations [41].
In three small studies, letrozole or testolactone has been administered to morbidly obese men to improve their testosterone levels [42-44]. Treatment resulted in normalization of testosterone levels in all subjects, with a concomitant suppression of the originally increased levels of estradiol. This normalization of the estradiol/ testosterone ratio might be of advantage, because of the suppressive effects of testosterone on the expression of the estrogen receptor $\beta$, which in itself, in the presence of high levels of estradiol, can suppress the expression of GLUT-4, leading to insulin insensitivity [45]. A case study describes a morbidly obese infertile man, who after a similar treatment with anastrozole showed a normalized pituitary-testis axis, spermatogenesis and fertility [46]. However, testosterone levels will also improve on weight loss [47], which is the intervention of choice for obese men with or without low testosterone levels.

\section{Effects of aromatase inhibition on release of follicle- stimulating hormone and spermatogenesis}

Although FSH release is primarily under the control of inhibin, circulating estradiol has a substantial effect on FSH levels in men [28]. Aromatase inhibition results in a three-fold increase in levels of FSH $[28,29]$ in eugonadal men and may potentially stimulate sperm production. Earlier studies using tamoxifen or clomifene to increase FSH levels did not show unequivocal evidence for the efficacy of this approach [48]. Uncontrolled studies using anastrozole, testolactone or letrozole have shown some evidence for a positive effect on sperm concentration and motility [49-51]. However, one double-blind crossover trial using testolactone did not show a significant improvement of sperm quality in men with oligospermia [52]. More recently, a study in which anastrozole was added to the treatment with tamoxifen in men with idiopathic oligoasthenoteratozoospermia and a decreased testosterone over estradiol ratio after treatment with tamoxifen alone indicated an increased pregnancy rate compared with the group without the addition of the aromatase inhibitor [53]. Finally, pretreatment with aromatase inhibitors was described to lead to positive results of testicular sperm extraction in Klinefelter's syndrome patients with low pretreatment testosterone concentrations: men from whose testes spermatozoa were retrieved showed higher posttreatment testosterone levels and testosterone over estradiol ratios compared to men in whom no spermatozoa could be obtained, whereas pretreatment levels of testosterone, LH and FSH did not predict the result of treatment outcome [54].

\section{Effects of aromatase inhibition on bone metabolism and epiphysial closure}

Estrogens are essential for epiphysial maturation in boys. Aromatase inhibitors, therefore, may be used to lower 
estradiol levels and thereby slow down epiphysial maturation. This approach proved successful in rare conditions such as the aromatase-excess syndrome [25] and high estrogen levels due to Sertoli cell tumors in boys with Peutz-Jeghers syndrome [55]. In boys with familial male precocious puberty due to activating mutations of the LH receptor, also known as testotoxicosis, treatment with an antiandrogen in combination with an aromatase inhibitor to prevent effects on bone is the treatment of choice. In an earlier study a combination of spironolactone and testolactone proved effective [56], whereas in later studies the combination of bicalutamide and anastrozole was used [57-59].

Aromatase inhibition has also been studied in boys with idiopathic short stature. Boys with a mean age of 11 years at the start of the study were treated with letrozole $2.5 \mathrm{mg}$ once daily or placebo for 2 years [60]. Letrozole treatment was associated with higher plasma levels of gonadotropins and testosterone in boys who entered puberty during the study. In spite of this fact, plasma estradiol levels were mostly lower in the letrozole-treated group. Both groups showed similar growth velocity but bone age progressed significantly slower in the letrozole group resulting in a gain of $5.9 \mathrm{~cm}$ in predicted adult height. The fact that growth velocity was not affected is remarkable in the light of the observation, that in adult men treated with a combination of testosterone and anastrozole the responses to GH secretagogues were smaller than in men treated with a combination of testosterone and a placebo; the $\mathrm{GH}$ and IGF-1 concentrations were positively correlated with estradiol levels [61]. Also in letrozole-treated boys in whom treatment started at the beginning of puberty, IGF-I levels were lower than in placebo-treated controls [62]. As expected, GH-deficient boys treated with $\mathrm{GH}$ and anastrozole showed a larger increase in height than their GH only-treated controls [63].

Boys with constitutional delay of puberty are typically small for their age and final adult height is often in the low-normal range. These boys may be treated with androgens to induce puberty. Although testosterone induces growth velocity, the estrogens aromatized from testosterone will accelerate epiphysial maturation and for that reason reduce adult height further. The combination of testosterone and letrozole, therefore, was tested in boys with constitutional delay of puberty. This combination treatment effectively increased growth velocity but epiphysial maturation was slower in the letrozole-treated group, leading to a significant increase in predicted adult height $[64,65]$.

\section{Effects of aromatase inhibition on male breast}

Aromatase inhibitors are widely prescribed for hormoneresponsive breast carcinoma in postmenopausal women.
It is well known that aromatase inhibition results in a dramatic reduction of tumor estrogen concentrations [66]. As gynecomastia in men presumably results from an imbalance between androgen and estrogen action, aromatase inhibition was tested as a treatment for gynecomastia in boys. Treatment with anastrozole daily for 6 months, however, did not result in a significant improvement compared with placebo [67]. This is in accordance with the data summarized in a recent review [68], describing similar responses to placebo, tamoxifen and anastrozole in a number of observational studies. Anastrozole was also studied in a group of prostate cancer patients treated with bicalutamide, an androgen antagonist. A dose of $1 \mathrm{mg}$ daily appeared to be mildly effective against the appearance of gynecomastia. Tamoxifen was much more effective, however, in the prevention of gynecomastia in these men $[69,70]$. Due to these disappointing results, aromatase inhibitors are not recommended as a first-line treatment for gynecomastia in men.

Data on treatment of male mammary tumors with aromatase inhibitors are scarce and indicate that this treatment modality is unlikely to be successful because of the unwanted effect of increased levels of testosterone, making it impossible to reach the low estradiol levels obtained in postmenopausal women after this treatment [71]. The combination with a GnRH analog in order to prevent this increase did not yield beneficial results either [72].

\section{Safety and concerns for aromatase inhibitors in men}

Extensive experience with third-generation aromatase inhibitors in postmenopausal women did not reveal major side effects related to their use. Long-term use in postmenopausal women is associated with a moderate increase in bone resorption and a modest decrease in BMD compared with placebo [2,3]. As outlined above, low BMD is a characteristic sign of aromatase deficiency but also in normal men most cross-sectional studies showed that bioavailable or total estradiol levels are associated with BMD [73-77]. The primary concern, therefore, associated with aromatase inhibition in men is the negative effect it may have on bone metabolism. In most studies utilizing aromatase inhibitors in men estradiol levels decreased only moderately. Additionally, the suppression of plasma estradiol levels in men is associated with an increase in gonadotropin levels, which stimulate the production of testosterone, the main precursor for estradiol synthesis. Khosla et al. [76,78] proposed a threshold for bioavailable estradiol of $30 \mathrm{pM}$, below which BMD appeared to be strongly and negatively associated with the plasma bioavailable estradiol concentration in men. Thresholds should be interpreted with great caution because they rely heavily on the methods used to measure total or bioavailable estradiol 
levels. These authors used ammonium sulfate precipitation to measure bioavailable estradiol levels whereas if they had calculated bioavailable estradiol levels using the popular Sodergard equation $[79,80]$ their proposed threshold may have been as high as $75 \mathrm{pM}$. In experimental settings, selective withdrawal of estradiol in men was associated with an increase in markers of bone resorption $[30,81]$. In the studies published so far aromatase inhibition in men did not appear to be associated with adverse effects on bone in a number of studies $[37,59,82,83]$, but in a more recent study a decrease of spine BMD was observed after one year of treatment of elderly men with anastrozole [84]. Additionally, one short-term study did not show adverse effects of aromatase inhibition in older men on cardiovascular markers. However, it is not clear that this conclusion also holds for boys: vertebral deformities were observed in boys treated for delayed onset of puberty [85]. Furthermore, hyperandrogenism induced by treatment with aromatase inhibitors may result in decreased HDL-cholesterol and increased hemoglobin levels [86], indicating the need for follow-up during treatment. The same group of investigators concluded that there were no effects of letrozole on cognitive performance could be detected in a group of prepubertal boys [87]. In a group of elderly men who obtained exogenous testosterone enenthate, the addition of anastrozole to the injected androgen prevented the androgen induced improvement of verbal memory, but did not affect special memory [88].

\section{Conclusion}

Over the years compelling evidence has accumulated that in men estradiol has an important role in gaining and maintaining bone mass, closing of the epiphyses and feedback on gonadotrophin release. Aromatase inhibitors, mostly combined with agonists of gonadotrophin-releasing hormone proved effective for the prevention of premature epiphysial closure in boys with pubertas praecox of various etiologies. There is also evidence that aromatase inhibitors can be used in boys with idiopathic short stature and boys with constitutional delay of puberty to increase adult height. Aromatase inhibitors are not effective for the treatment of gynecomastia in pubertal boys and have limited efficacy for the prevention of gynecomastia in bicalutamide-treated men with prostate cancer. Although aromatase inhibitors increase FSH levels, there is no consistent evidence for a beneficial effect on spermatogenesis. In older men with so-called late-onset hypogonadism, aromatase inhibitors may emerge as an attractive alternative for traditional testosterone supplementation to improve testosterone levels. The long-term benefits of higher testosterone levels in older men remain controversial, however. Moreover, it is questionable whether aromatase inhibitors are able to stimulate testosterone production sufficiently in men with truly low testosterone levels for whom testosterone treatment is currently recommended. Although most of the recent studies with aromatase inhibitors in boys and adult men do not show major detrimental effects on bone long-term skeletal safety remains an issue of concern.

\section{Author details}

'Department of Internal Medicine, Kennemer Gasthuis, P.O. Box 417, 2000 AK Haarlem, The Netherlands. ${ }^{2}$ Department of Internal Medicine, Erasmus university Medical Center, P.O. Box 2040, 3000 CA, Rotterdam, The Netherlands.

\section{Authors' contributions}

WDR wrote the original version of this manuscript. FHDJ extended the text with more recent observations and conclusions. Both authors read and approved the final manuscript.

\section{Competing interests}

The authors declare that they have no competing interests.

Received: 1 March 2011 Accepted: 21 June 2011

Published: 21 June 2011

\section{References}

1. Jones ME, Boon WC, McInnes K, Maffei L, Carani C, Simpson ER: Recognizing rare disorders: aromatase deficiency. Nat Clin Pract Endocrinol Metab 2007, 3:414-421.

2. Perez EA, Josse RG, Pritchard KI, Ingle JN, Martino S, Findlay BP, Shenkier TN, Tozer RG, Palmer MJ, Shepherd LE, Liu S, Tu D, Goss PE: Effect of letrozole versus placebo on bone mineral density in women with primary breast cancer completing 5 or more years of adjuvant tamoxifen: a companion study to NCIC CTG MA.17. J Clin Oncol 2006, 24:3629-3635.

3. Lønning PE, Geisler J, Krag LE, Erikstein B, Bremnes Y, Hagen Al, Schlichting E, Lien EA, Ofjord ES, Paolini J, Polli A, Massimini G: Effects of exemestane administered for 2 years versus placebo on bone mineral density, bone biomarkers, and plasma lipids in patients with surgically resected early breast cancer. J Clin Oncol 2005, 23:5126-5137.

4. de Ronde W: Therapeutic uses of aromatase inhibitors in men. Curr Opin Endocrinol Diabetes Obes 2007, 14:235-240.

5. Simpson ER, Davis SR: Minireview: aromatase and the regulation of estrogen biosynthesis-some new perspectives. Endocrinology 2001, 142:4589-4594.

6. Stoffel-Wagner B, Watzka M, Schramm J, Bidlingmaier F, Klingmüller D: Expression of CYP19 (aromatase) mRNA in different areas of the human brain. J Steroid Biochem Mol Biol 1999, 70:237-241.

7. Schindler $A E$, Ebert A, Friedrich E: Conversion of androstenedione to estrone by human tissue. J Clin Endocrinol Metab 1972, 35:627-630.

8. Bulun SE, Simpson ER: Competitive reverse transcription-polymerase chain reaction analysis indicates that levels of aromatase cytochrome P450 transcripts in adipose tissue of buttocks, thighs, and abdomen of women increase with advancing age. J Clin Endocrinol Metab 1994, 78:428-432.

9. Longcope $\mathrm{C}$, Pratt JH, Schneider SH, Fineberg SE: Aromatization of androgens by muscle and adipose tissue in vivo. J Clin Endocrinol Metab 1978, 46:146-152.

10. Schweikert HU, Milewich L, Wilson JD: Aromatization of androstenedione by isolated human hairs. J Clin Endocrinol Metab 1975, 40:413-417.

11. Schweikert HU, Wolf $L$, Romalo G: Oestrogen formation from androstenedione in human bone. Clin Endocrinol (Oxf) 1995, 43:37-42.

12. Harada N, Sasano H, Murakami H, Ohkuma T, Nagura H, Takagi Y: Localized expression of aromatase in human vascular tissues. Circ Res 1999, 84:1285-1291.

13. Baird DT, Horton R, Longcope C, Tait JF: Steroid dynamics under steadystate conditions. Recent Prog Horm Res 1969, 25:611-664. 
14. MacDonald PC, Madden JD, Brenner PF, Wilson JD, Siiteri PK: Origin of estrogen in normal men and in women with testicular feminization. $J$ Clin Endocrinol Metab 1979, 49:905-916.

15. de Ronde W, Hofman A, Pols HA, de Jong FH: A direct approach to the estimation of the origin of oestrogens and androgens in elderly men by comparison with hormone levels in postmenopausal women. Eur $\mathrm{J}$ Endocrinol 2005, 152:261-268.

16. de Ronde W, van der Schouw YT, Muller M, Grobbee DE, Gooren LJ, Pols HA, de Jong FH: Associations of sex hormone binding globulin (SHBG) with non-SHBG-bound levels of testosterone and estradiol in independently living men. J Clin Endocrinol Metab 2005, 90:157-162.

17. Carani C, Qin K, Simoni M, Faustini-Fustini M, Serpente S, Boyd J, Korach KS, Simpson ER: Effect of testosterone and estradiol in a man with aromatase deficiency. N Engl J Med 1997, 337:91-95.

18. Maffei L, Murata Y, Rochira V, Tubert G, Aranda C, Vazquez M, Clyne CD, Davis S, Simpson ER, Carani C: Dysmetabolic syndrome in a man with a novel mutation of the aromatase gene: effects of testosterone, alendronate, and estradiol treatment. J Clin Endocrinol Metab 2004, 89:61-70.

19. Morishima A, Grumbach MM, Simpson ER, Fisher C, Qin K: Aromatase deficiency in male and female siblings caused by a novel mutation and the physiological role of estrogens. J Clin Endocrinol Metab 1995, 80:3689-3698.

20. Herrmann BL, Saller B, Janssen OE, Gocke P, Bockisch A, Sperling H, Mann K, Broecker M: Impact of estrogen replacement therapy in a male with congenital aromatase deficiency caused by a novel mutation in the CYP19 gene. J Clin Endocrinol Metab 2002, 87:5476-5484.

21. Mittre Hervé MH, Kottler Ml, Pura M: Human gene mutations. Gene symbol: CYP19. Diseaese: aromatase deficiency. Hum Genet 2004, 114:124

22. Bouillon R, Bex M, Vanderschueren D, Boonen S: Estrogens are essential for male pubertal periosteal bone expansion. J Clin Endocrinol Metab 2004, 89:6025-6029.

23. Lanfranco F, Pignatti E, Corneli G, Ghigo E, Aimaretti G, Carani C, Rochira V: A novel mutation in the human aromatase gene: insights on the relationship among serum estradiol, longitudinal growth and bone mineral density in an adult man under estrogen replacement treatment. Bone 2008, 43:628-635.

24. Deladoëy J, Flück C, Bex M, Yoshimura N, Harada N, Mullis PE: Aromatase deficiency caused by a novel P450arom gene mutation: impact of absent estrogen production on serum gonadotropin concentration in a boy. J Clin Endocrinol Metab 1999, 84:4050-4054.

25. Stratakis CA, Vottero A, Brodie A, Kirschner LS, DeAtkine D, Lu Q, Yue W, Mitsiades CS, Flor AW, Chrousos GP: The aromatase excess syndrome is associated with feminization of both sexes and autosomal dominant transmission of aberrant P450 aromatase gene transcription. J Clin Endocrinol Metab 1998, 83:1348-1357.

26. Shozu M, Sebastian S, Takayama K, Hsu WT, Schultz RA, Neely K, Bryant M, Bulun SE: Estrogen excess associated with novel gain-of-function mutations affecting the aromatase gene. N Engl J Med 2003, 348:1855-1865.

27. Thürlimann B, Keshaviah A, Coates AS, Mouridsen H, Mauriac L, Forbes JF, Paridaens R, Castiglione-Gertsch M, Gelber RD, Rabaglio M, Smith I, Wardley A, Price KN, Goldhirsch A: A comparison of letrozole and tamoxifen in postmenopausal women with early breast cancer. $N$ Engl J Med 2005, 353:2747-2757.

28. Raven G, de Jong FH, Kaufman JM, de Ronde W: In men, peripheral estradiol levels directly reflect the action of estrogens at the hypothalamo-pituitary level to inhibit gonadotropin secretion. $J$ Clin Endocrinol Metab 2006, 91:3324-3328

29. T'sjoen GG, Giagulli VA, Delva H, Crabbe P, De Bacquer D, Kaufman JM: Comparative assessment in young and elderly men of the gonadotropin response to aromatase inhibition. J Clin Endocrinol Metab 2005, 90:5717-5722.

30. Falahati-Nini A, Riggs BL, Atkinson EJ, O'Fallon WM, Eastell R, Khosla S: Relative contributions of testosterone and estrogen in regulating bone resorption and formation in normal elderly men. J Clin Invest 2000, 106:1553-1560

31. Geisler J, Haynes B, Anker G, Dowsett M, Lønning PE: Influence of letrozole and anastrozole on total body aromatization and plasma estrogen levels in postmenopausal breast cancer patients evaluated in a randomized, cross-over study. J Clin Oncol 2002, 20:751-757.
32. Pitteloud N, Dwyer AA, DeCruz S, Lee H, Boepple PA, Crowley WF Jr, Hayes FJ: Inhibition of luteinizing hormone secretion by testosterone in men requires aromatization for its pituitary but not its hypothalamic effects: evidence from the tandem study of normal and gonadotropinreleasing hormone-deficient men. J Clin Endocrinol Metab 2008, 93:784-791.

33. Kaufman JM, Vermeulen A: The decline of androgen levels in elderly men and its clinical and therapeutic implications. Endocr Rev 2005, 26:833-876.

34. Bhasin S, Cunningham GR, Hayes FJ, Matsumoto AM, Snyder PJ, Swerdloff RS, Montori VM: Testosterone therapy in adult men with androgen deficiency syndromes: an endocrine society clinical practice guideline. J Clin Endocrinol Metab 2006, 91:1995-2010.

35. Nieschlag E, Swerdloff R, Behre HM, Gooren LJ, Kaufman JM, Legros JJ, Lunenfeld B, Morley JE, Schulman C, Wang C, Weidner W, Wu FC: Investigation, treatment and monitoring of late-onset hypogonadism in males: ISA, ISSAM, and EAU recommendations. Int J Androl 2005, 28:125-127.

36. Leder BZ, Rohrer JL, Rubin SD, Gallo J, Longcope C: Effects of aromatase inhibition in elderly men with low or borderline-low serum testosterone levels. J Clin Endocrinol Metab 2004, 89:1174-1180.

37. Muller M, van den Beld AW, van der Schouw YT, Grobbee DE, Lamberts SW: Effects of dehydroepiandrosterone and atamestane supplementation on frailty in elderly men. J Clin Endocrinol Metab 2006, 91:3988-3991.

38. Burnett-Bowie SA, Roupenian KC, Dere ME, Lee H, Leder BZ: Effects of aromatase inhibition in hypogonadal older men: a randomized, doubleblind, placebo-controlled trial. Clin Endocrinol (Oxf) 2009, 70:116-123.

39. Snyder PJ, Peachey H, Hannoush P, Berlin JA, Loh L, Holmes JH, Dlewati A, Staley J, Santanna J, Kapoor SC, Attie MF, Haddad JG Jr, Strom BL: Effect of testosterone treatment on bone mineral density in men over 65 years of age. J Clin Endocrinol Metab 1999, 84:1966-1972.

40. Kley HK, Deselaers T, Peerenboom H, Kruskemper HL: Enhanced conversion of androstenedione to estrogens in obese males. J Clin Endocrinol Metab 1980, 51:1128-1132.

41. Strain GW, Zumoff B, Miller LK, Rosner W, Levit C, Kalin M, Hershcopf RJ, Rosenfeld RS: Effect of massive weight loss on hypothalamic-pituitarygonadal function in obese men. J Clin Endocrinol Metab 1988, 66:1019-1023.

42. de Boer H, Verschoor L, Ruinemans-Koerts J, Jansen M: Letrozole normalizes serum testosterone in severely obese men with hypogonadotropic hypogonadism. Diabetes Obes Metab 2005, 7:211-215.

43. Zumoff B, Miller LK, Strain GW: Reversal of the hypogonadotropic hypogonadism of obese men by administration of the aromatase inhibitor testolactone. Metabolism 2003, 52:1126-1128.

44. Loves S, Ruinemans-Koerts J, de Boer H: Letrozole once a week normalizes serum testosterone in obesity-related male hypogonadism. Eur J Endocrinol 2008, 158:741-747.

45. Cohen PG: Obesity in men: the hypogonadal-estrogen receptor relationship and its effect on glucose homeostasis. Med Hypotheses 2008, 70:358-360.

46. Roth MY, Amory JK, Page ST: Treatment of male infertility secondary to morbid obesity. Nat Clin Pract Endocrinol Metab 2008, 4:415-419.

47. Vermeulen A, Kaufman JM, Giagulli VA: Influence of some biological indexes on sex hormone-binding globulin and androgen levels in aging or obese males. J Clin Endocrinol Metab 1996, 81:1821-1826.

48. Vandekerckhove P, Lilford R, Vail A, Hughes E: Clomiphene or tamoxifen for idiopathic oligo/asthenospermia. Cochrane Database Syst Rev 2000, 2: CD000151

49. Pavlovich $C P$, King P, Goldstein $M$, Schlegel PN: Evidence of a treatable endocrinopathy in infertile men. J Urol 2001, 165:837-841.

50. Raman JD, Schlegel PN: Aromatase inhibitors for male infertility. J Urol 2002, 167:624-629

51. Saylam B, Efesoy O, Cayan S: The effect of aromatase inhibitor letrozole on body mass index, serum hormones, and sperm parameters in infertile men. Fertil Steril 2011, 95:809-811.

52. Clark RV, Sherins RJ: Treatment of men with idiopathic oligozoospermic infertility using the aromatase inhibitor, testolactone. Results of a doubleblinded, randomized, placebo-controlled trial with crossover. $J$ Androl 1989, 10:240-247.

53. Cakan M, Aldemir M, Topcuoglu M, Altuğ U: Role of testosterone/estradiol ratio in predicting the efficacy of tamoxifen citrate treatment in idiopathic oligoasthenoteratozoospermic men. Urol Int 2009, 83:446-451. 
54. Ramasamy R, Ricci JA, Palermo GD, Gosden LV, Rosenwaks Z, Schlegel PN: Successful fertility treatment for Klinefelter's syndrome. J Urol 2009, 182:1108-1113.

55. Lefevre H, Bouvattier C, Lahlou N, Adamsbaum C, Bougnères P, Carel JC: Prepubertal gynecomastia in Peutz- Jeghers syndrome: incomplete penetrance in a familial case and management with an aromatase inhibitor. Eur J Endocrinol 2006, 154:221-227.

56. Laue L, Jones J, Barnes KM, Cutler GB Jr: Treatment of familial male precocious puberty with spironolactone, testolactone, and deslorelin. J Clin Endocrinol Metab 1993, 76:151-155.

57. Kreher NC, Pescovitz OH, Delameter P, Tiulpakov A, Hochberg Z: Treatment of familial male-limited precocious puberty with bicalutamide and anastrozole. J Pediatr 2006, 149:416-420.

58. Reiter EO, Mauras N, McCormick K, Kulshreshtha B, Amrhein J, De Luca F, O'Brien S, Armstrong J, Melezinkova H: Bicalutamide plus anastrozole for the treatment of gonadotropin-independent precocious puberty in boys with testotoxicosis: a phase II, open-label pilot study (BATT). J Pediatr Endocrinol Metab 2010, 23:999-1009.

59. Lenz AM, Shulman D, Eugster EA, Rahhal S, Fuqua JS, Pescovitz OH, Lewis KA: Bicalutamide and third-generation aromatase inhibitors in testotoxicosis. Pediatrics 2010, 126:e728-e733.

60. Hero M, Norjavaara E, Dunkel L: Inhibition of estrogen biosynthesis with a potent aromatase inhibitor increases predicted adult height in boys with idiopathic short stature: a randomized controlled trial. J Clin Endocrinol Metab 2005, 90:6396-6402.

61. Veldhuis JD, Mielke KL, Cosma M, Soares-Welch C, Paulo R, Miles JM, Bowers CY: Aromatase and 5alpha-reductase inhibition during an exogenous testosterone clamp unveils selective sex steroid modulation of somatostatin and growth hormone secretagogue actions in healthy older men. J Clin Endocrinol Metab 2009, 94:973-981.

62. Hero M, Mäkitie $O$, Kröger H, Nousiainen E, Toiviainen-Salo S, Dunkel L: Impact of aromatase inhibitor therapy on bone turnover, cortical bone growth and vertebral morphology in pre- and peripubertal boys with idiopathic short stature. Horm Res 2009, 71:290-297.

63. Mauras N, Gonzalez de Pijem L, Hsiang HY, Desrosiers P, Rapaport R, Schwartz ID, Klein KO, Singh RJ, Miyamoto A, Bishop K: Anastrozole increases predicted adult height of short adolescent males treated with growth hormone: a randomized, placebo-controlled, multicenter trial for one to three years. J Clin Endocrinol Metab 2008, 93:823-831.

64. Wickman S, Sipila I, Ankarberg-Lindgren C, Norjavaara E, Dunkel L: A specific aromatase inhibitor and potential increase in adult height in boys with delayed puberty a randomised controlled trial. Lancet 2001 357:1743-1748.

65. Hero M, Wickman S, Dunkel L: Treatment with the aromatase inhibitor letrozole during adolescence increases near-final height in boys with constitutional delay of puberty. Clin Endocrinol (Oxf) 2006, 64:510-513.

66. Van Landeghem AA, Poortman J, Nabuurs M, Thijssen $\mathrm{JH}$ : Endogenous concentration and subcellular distribution of estrogens in normal and malignant human breast tissue. Cancer Res 1985, 45:2900-2906.

67. Plourde PV, Reiter EO, Jou HC, Desrochers PE, Rubin SD, Bercu BB Diamond FB Jr, Backeljauw PF: Safety and efficacy of anastrozole for the treatment of pubertal gynecomastia: a randomized, double-blind, placebocontrolled trial. J Clin Endocrinol Metab 2004, 89:4428-4433.

68. Maidment SL: Question 2. Which medications effectively reduce pubertal gynaecomastia? Arch Dis Child 2010, 95:237-9.

69. Boccardo F, Rubagotti A, Battaglia M, Di Tonno P, Selvaggi FP, Conti G, Comeri G, Bertaccini A, Martorana G, Galassi P, Zattoni F, Macchiarella A, Siragusa A, Muscas G, Durand F, Potenzoni D, Manganelli A, Ferraris V, Montefiore F: Evaluation of tamoxifen and anastrozole in the prevention of gynecomastia and breast pain induced by bicalutamide monotherapy of prostate cancer. J Clin Oncol 2005, 23:808-815.

70. Saltzstein D Sieber P, Morris T, Gallo J: Prevention and management of bicalutamide-induced gynecomastia and breast pain: randomized endocrinologic and clinical studies with tamoxifen and anastrozole. Prostate Cancer Prostatic Dis 2005, 8:75-83.

71. Hayes TG: Pharmacologic treatment of male breast cancer. Exp Opin Pharmacother 2009, 10:2499-2510.

72. Soon Wong N, Seong Ooi W, Pritchard Kl: Role of gonadotropin-releasing hormone analog in the management of male metastatic breast cancer is uncertain. J Clin Oncol 2007, 25:3787.
73. Amin S, Zhang Y, Sawin CT, Evans SR, Hannan MT, Kiel DP, Wilson PW, Felson DT: Association of hypogonadism and estradiol levels with bone mineral density in elderly men from the Framingham study. Ann Intern Med 2000, 133:951-963.

74. Szulc P, Munoz F, Claustrat B, Garnero P, Marchand F, Duboeuf F, Delmas PD: Bioavailable estradiol may be an important determinant of osteoporosis in men: the MINOS study. J Clin Endocrinol Metab 2001, 86:192-199.

75. Khosla S, Melton LJ III, Atkinson EJ, O'Fallon WM, Klee GG, Riggs BL: Relationship of serum sex steroid levels and bone turnover markers with bone mineral density in men and women: a key role for bioavailable estrogen. J Clin Endocrinol Metab 1998, 83:2266-2274

76. Khosla S, Melton $\sqcup$ III, Atkinson EJ, O'Fallon WM: Relationship of serum sex steroid levels to longitudinal changes in bone density in young versus elderly men. J Clin Endocrinol Metab 2001, 86:3555-3561.

77. Gennari L, Merlotti D, Martini G, Gonnelli S, Franci B, Campagna S, Lucani B, Dal Canto N, Valenti R, Gennari C, Nuti R: Longitudinal association between sex hormone levels, bone loss, and bone turnover in elderly men. J Clin Endocrinol Metab 2003, 88:5327-5333.

78. Khosla S, Melton LJ III, Robb RA, Camp JJ, Atkinson EJ, Oberg AL, Rouleau PA, Riggs BL: Relationship of volumetric BMD and structural parameters at different skeletal sites to sex steroid levels in men. $J$ Bone Miner Res 2005, 20:730-740.

79. Sodergard R, Backstrom T, Shanbhag V, Carstensen H: Calculation of free and bound fractions of testosterone and estradiol-17 beta to human plasma proteins at body temperature. J Steroid Biochem 1982, 16:801-810.

80. Szulc P, Claustrat B, Munoz F, Marchand F, Delmas PD: Assessment of the role of 17 beta-oestradiol in bone metabolism in men: does the assay technique matter? The MINOS study. Clin Endocrinol (Oxf) 2004, 61:447-457.

81. Leder BZ, LeBlanc KM, Schoenfeld DA, Eastell R, Finkelstein JS: Differential effects of androgens and estrogens on bone turnover in normal men. $J$ Clin Endocrinol Metab 2003, 88:204-210.

82. Leder BZ, Finkelstein JS: Effect of aromatase inhibition on bone metabolism in elderly hypogonadal men. Osteoporos Int 2005, 16:1487-1494.

83. Wickman S, Kajantie E, Dunkel L: Effects of suppression of estrogen action by the p450 aromatase inhibitor letrozole on bone mineral density and bone turnover in pubertal boys. J Clin Endocrinol Metab 2003, 88:3785-3793.

84. Burnett-Bowie SA, McKay EA, Lee H, Leder BZ: Effects of aromatase inhibition on bone mineral density and bone turnover in older men with low testosterone levels. J Clin Endocrinol Metab 2009, 94:4785-4792.

85. Hero M, Toiviainen-Salo S, Wickman S, Mäkitie O, Dunkel L: Vertebral morphology in aromatase inhibitor-treated males with idiopathic short stature or constitutional delay of puberty. J Bone Miner Res 2010, 25:1536-1543.

86. Hero M, Ankarberg-Lindgren C, Taskinen MR, Dunkel L: Blockade of oestrogen biosynthesis in peripubertal boys: effects on lipid metabolism, insulin sensitivity and body composition. Eur J Endocrinol 2006, 155:453-460.

87. Hero M, Maury S, Luotoniemi E, Service E, Dunkel L: Cognitive effects of aromatase inhibitor therapy in peripubertal boys. Eur J Endocrinol 2010, 163:149-155.

88. Cherrier MM, Matsumoto AM, Amory JK, Ahmed S, Bremner W, Peskind ER, Raskind MA, Johnson M, Craft S: The role of aromatization in testosterone supplementation: effects on cognition in older men. Neurology 2005, 64:290-296.

doi:10.1186/1477-7827-9-93

Cite this article as: de Ronde and de Jong: Aromatase inhibitors in men: effects and therapeutic options. Reproductive Biology and Endocrinology 2011 9:93. 